\title{
An assessment of heavy metal bioaccumulation in Asian Swamp Eel, Monopterus albus, during plowing stages of a paddy cycle
}

\begin{abstract}
Livers and muscles of swamp eels (Monopterus albus) were analyzed for bioaccumulation of heavy metals during the plowing stage of a paddy cycle. Results showed heavy metals were bioaccumulated more highly in liver than muscle. Zinc ( $\mathrm{Zn})$ was the highest bioaccumulated metal in liver $(98.5 \pm 8.95 \mu \mathrm{g} / \mathrm{g})$ and in muscle $(48.8 \pm 7.17 \mu \mathrm{g} / \mathrm{g})$. The lowest bioaccumulated metals were cadmium $(\mathrm{Cd})$ in liver $(3.44 \pm 2.42 \mu \mathrm{g} / \mathrm{g})$ and copper $(\mathrm{Cu})$ in muscle $(0.65 \pm 0.20 \mu \mathrm{g} / \mathrm{g})$. In sediments, $\mathrm{Zn}$ was present at the highest mean concentration $(52.7 \pm 2.85 \mu \mathrm{g} / \mathrm{g})$, while $\mathrm{Cd}$ had the lowest mean concentration $(1.04 \pm 0.24 \mu \mathrm{g} / \mathrm{g})$. The biota-sediment accumulation factor (BSAF) for $\mathrm{Cu}, \mathrm{Zn}, \mathrm{Cd}$ and nickel (Ni) in liver tissue was greater than the corresponding BSAF for muscle tissue. For the three plowing stages, metal concentrations were significantly correlated between liver and muscle tissues in all cases, and between sediment and either liver or muscle in most cases. Mean measured metal concentrations in muscle tissue were below the maximum permissible limits established by Malaysian and U.S. governmental agencies, and were therefore regarded as safe for human consumption.
\end{abstract}

Keyword: Bioaccumulation; Heavy metals; Plowing stages; Swamp eel. 